Bull. Fac. Agric, Cairo Univ., 69:427-435 (2018).

\title{
PREVALENCE OF ANTIBIOTIC RESISTANT BACTERIA IN NILE WATER AND SEWAGE TREATMENT PLANTS
}

(Received: 29.10.2018)

\author{
By \\ Dina A. Ahmed, Hanan A. Goda and R. I. Refae \\ Department of Microbiology, Faculty of Agriculture Cairo University, Giza, Egypt
}

\begin{abstract}
The overuse of antibiotics has contributed to the rapid spread of antibiotic resistant bacteria which led to increasing interest about the potential environmental and public health risks. This study is concerned with evaluating the prevalence of antibiotic resistant bacteria (ARB) in raw and treated Nile water and sewage. It is obvious that, the drinking water treatment in all drinking water treatment plants (DWTPs) was microbiologically effective as the total bacterial community and antibiotics resistant bacteria were completely removed from treated Nile water and tap water samples. Only, in El-Giza DWTP, the bacterial populations reappeared in tap water with low values comparing with raw Nile water. The counts of bacterial population, gentamycin, ciprofloxacin, doxycycline and amoxicillin resistant bacteria in tap water represented $0.0008,0.72,1.02,90.9$ and $0.6 \%$ of the counts in raw Nile water, respectively. Also, it was observed that, the counts of total bacteria, gentamycin, ciprofloxacin, doxycycline and amoxicillin resistant bacteria decreased in treated sewage at a reduction percentage of 54.5, 76.9, 73.3, 84.0 and 77.3\%, respectively. Additionally, the counts of total coliforms, doxycycline and amoxicillin resistant bacteria decreased at a reduction ration of 99.7, 98.1 and 95.7\%, respectively in treated sewage. Most bacterial isolates from raw Nile water and sewage were multi antibiotic resistant Gram-negative short rods.
\end{abstract}

Key words: antibiotic-resistant bacteria, prevalence, Nile water, sewage treatment.

\section{INTRODUCTION}

The misapplication of antibiotics in medicine and agriculture triggered a reduction of their efficiency against most infectious diseases. The World Health Organization (WHO) reported that spreading the antibiotic resistant bacteria is one of the most important worldwide threats to health and food security (Leonard et al., 2015). Also, it was stated that, 700.000 people die every year due to the infections caused by antibiotic resistant bacteria and it is expected to raise up to 10 million by 2050 .

The bacterial resistance to antibiotics may be intrinsic or acquired as a result of selective pressure of antimicrobial substances present in the environment. Also, it maybe the result of a process of horizontal gene transfer (HGT) between microorganisms via conjugation, transformation, transduction and transposition (Davies, 2006; Martinez, 2008 and Marti et al., 2014).

The antibiotic resistant bacteria (ARB) and antibiotic resistant genes (ARGs) are extensively present in diverse environments, including surface water, ground water, soil and sediments, where they have the potential to be transferred from host bacteria to pathogens by HGT as aforementioned (Pruden et al., 2012; Cytryn, 2013; Ma and Zhang., 2014 and Osinska et al., 2017). Currently, ARGs are considered as evolving pollutants and their dissemination in the environment has received extensive attention.

The chemical and microbial water quality is the concern of all countries in the world. The WHO emphasized that, the potable water should meet the high requirements of hygiene and should at least be free of pathogenic organisms and toxic substance (Vozmaya, 1983 and Abdo, 2005). Factually, evaluating the microbial quality of drinking water has been focused on the incidence of pathogens in drinking water distribution systems. However, the presence of trace levels of antibiotics and ARB in the source water and drinking water may also significantly affect the public health (Schwartz et al., 2003; Berry et al., 2006 and $\mathrm{Xi}$ et al., 2009). Numerous studies have stated that, ARB are 
found normally in drinking water (Armstrong et al., 1982; Ramteke et al., 1990; Shrivastava et al., 2004 and Pathak and Gopal, 2008). The study carried out by Walia et al. (2004) has recorded higher number of multiple antibiotics resistant $E$. coli in drinking water as compared to the human urine samples.

Waste water treatment plants (WWTPs) are considered as an important source of ARB and ARGs which persist in the effluent representing a major source of their dissemination in the environment through its discharging to the surface water. The high content of both microbial biomass and nutrients in the wastewater provide advantageous conditions for the survival of ARB and transfer of ARGs (Michael et al., 2013 and Devarajan et al., 2016).

The intended objective of this study is evaluating the occurrence of the antibiotic resistant bacteria in different Egyptian water types comprising Nile water, and domestic waste water (sewage).

\section{MATERIALS AND METHODS}

\subsection{Water and sewage samples collection}

During this study, a total of 11 water and sewage samples were congregated from Giza Governorate. Six samples were collected from three drinking water treatment plants (DWTPs); El - Giza, El - Waraq and Gezeret El-Dahab.

These samples were represented as three untreated water samples withdrawn from the inlet of plant and three treated water samples as effluents discharged in the drinking water distribution systems. Three samples of drinking water were collected as tap water after passing through water distribution systems. The sewage samples, collected from Zenin wastewater treatment plant (WWTP), comprised one sample of each raw sewage and treated sewage. All samples were kept in icebox to transfer to the lab and refrigerated at $4^{\circ} \mathrm{C}$ for not more than one day until examined.

\subsection{Microbiological analysis of water and sewage samples}

The microbiological analysis included determination of the following microbial groups:

\subsubsection{Total aerobic bacterial count}

The pour - plate method was used to determine the total aerobic count of heterotrophic bacteria applying the incubation conditions of $30 \pm 2^{\circ} \mathrm{C}$ for $48 \mathrm{~h}$ using nutrient agar medium. The counts per $\mathrm{ml}$ of the sample were calculated as $\mathrm{cfu} / \mathrm{ml}$.

\subsubsection{Total bacterial count resistant to antibiotics}

The count of bacteria resistant to gentamicin, ciprofloxacin, doxycycline and amoxicillin were determined using nutrient agar supplemented with the mentioned antibiotics with a concentration of $8.0, \quad 2.0, \quad 8.0, \quad 4.0 \mathrm{mg} / \mathrm{l}$, respectively.

\subsubsection{Total and fecal coliforms}

The coliforms were determined in MacConkey broth applying the most probable number technique (MPN). The inoculated tubes were incubated at $37^{\circ} \mathrm{C}$ or $44.5^{\circ} \mathrm{C} / 24-48 \mathrm{~h}$ for determining the counts of total coilforms or fecal coliforms, respectively. The tubes were examined for production of acid and gas from lactose. Probability tables were used to calculate the MPN/ml (Pochon and Tardieux, 1962).

\subsubsection{Fecal streptococci}

The most probable number (MPN) method was applied to determine the count of fecal streptococci using glucose azide broth according to the method mentioned in Harrigan (1998).

\subsubsection{Fecal indicators resistant to antibiotics}

The counts of total coliforms, fecal coliforms and fecal streptococci resistant to gentamicin, ciprofloxacin, doxycycline and amoxicillin were estimated using the appropriate broth media supplemented with the antibiotics with a concentration of $8.0,2.0,8.0,4.0 \mathrm{mg} / \mathrm{ml}$, respectively.

\subsubsection{Antibiotic susceptibility test}

Antimicrobial susceptibility test was conducted applying the standard Kirby-Bauer disc diffusion technique (Bauer et al., 1966). To perform this test, some different colonies were selected randomly from the plates used to determine the total bacterial count resistant to gentamicin, ciprofloxacin, doxycycline and amoxicillin in raw Nile water and sewage. Suspension of each colony was prepared in Tryptone glucose yeast extract broth. One loop from each bacterial suspension was inoculated on the surface of Muller - Hinton agar and the antibiotic discs were placed on the surface of inoculated plates. Plates were incubated at $30 \pm 2^{\circ} \mathrm{C}$ for $18-24$ hours and diameter of the inhibition zones was measured in millimeters. Seven antibiotics were selected as representatives of six antibiotic classes (Table $1)$. 
Table (1): Antibiotics and antibiotic classes used in the antibiotic susceptibility test.

\begin{tabular}{|l|c|c|l|}
\hline \multicolumn{1}{|c|}{ Antibiotic name } & Abbreviation & Antibiotic dose on the disc $(\boldsymbol{\mu g})$ & \multicolumn{1}{c|}{ Antibiotic class } \\
\hline Amoxicillin & AMX & 25 & $\beta$-lactam antibiotics (penicillins) \\
\hline Gentamicin & GEN & 10 & Aminoglycosides \\
\hline Doxycycline & DX & 30 & Tetracyclines \\
\hline Ciprofloxacin & CIP & 5 & Fluoroquinolones \\
\hline Sulfamethoxazole & SXT & 25 & Sulfa Drugs \\
\hline Streptomycin & STR & 10 & Aminoglycosides \\
\hline Ampicillin & AM & 10 & $\beta$-lactam antibiotics (penicillins) \\
\hline
\end{tabular}

\section{RESULTS}

\subsection{Pervasiveness of antibiotic resistant} bacteria in water

The culture-dependent methods (pour - plate method and multiple-tube fermentation technique) were used to assess the prevalence of antibiotic resistant bacteria in collected water samples. Prevalence was defined as the percentage of total antibiotic resistant bacteria to total bacterial count (Xi et al., 2009).

Results in (Table 2) reveal that increasing the bacterial counts resistant to gentamycin $\left(1.12 \times 10^{4} \mathrm{cfu} / \mathrm{ml}\right)$, ciprofloxacin $\left(6.2 \times 10^{3} \mathrm{cfu} / \mathrm{ml}\right)$ and amoxicillin $\left(1.85 \times 10^{4} \mathrm{cfu} / \mathrm{ml}\right)$ in raw Nile water withdrawn from El-Giza DWTP comparing with samples from El-Waraq and Gezeret El-Dahab DWTPs.

Conversely, the greatest prevalence of the gentamycin, ciprofloxacin and doxycycline resistant bacteria was evident in raw Nile water from El-Waraq DWTP. The results show that, $39.13 \%, 43.48 \%$ and $35.22 \%$ of the total bacterial count were resistant to gentamycin, ciprofloxacin and doxycycline, respectively at the tested concentration. The amoxicillin resistant bacteria were observed with high incidence $(14.29 \%)$ in raw Nile water from Gezert El-Dahab DWTP.

The microbiological analysis of treated Nile water and tap water exhibited that, bacteria and antibiotics resistant bacteria were disappeared in samples withdrawn from El-Waraq and Gezeret El-Dahab DWTPs. The antibiotics resistant bacteria highly prevail led with different pattern in tap water withdrawn from El-Giza DWTP comparing with raw Nile water. The counts of gentamycin, ciprofloxacin, doxycycline and amoxicillin resistant bacteria represented $52.94 \%, 41.18 \%, 65.36 \%$ and $71.9 \%$ from the total bacterial count, respectively.

Total coliforms and coliforms resistant to the tested antibiotics appeared only in raw Nile water from El-Giza and Gezert El-Dahab DWTPs. The prevalence of these bacteria was comparatively weak. The occurrence of gentamycin, ciprofloxacin, doxycycline and

Table (2): Total bacterial count and counts of antibiotic resistant bacteria in raw and treated Nile water as well as drinking water.

\begin{tabular}{|c|c|c|c|c|c|c|}
\hline \multirow{2}{*}{$\begin{array}{l}\text { Sampling } \\
\text { site }\end{array}$} & \multirow[b]{2}{*}{ Water sample } & \multirow{2}{*}{$\begin{array}{c}\text { Total } \\
\text { count } \\
(\mathrm{cfu} / \mathrm{ml})\end{array}$} & \multicolumn{4}{|c|}{ Microbial count resistant to } \\
\hline & & & $\begin{array}{c}\text { Gentamycin } \\
(8.0 \mathrm{mg} / \mathrm{l}) \\
\end{array}$ & $\begin{array}{c}\text { Ciprofloxacin } \\
(2.0 \mathrm{mg} / \mathrm{l})\end{array}$ & $\begin{array}{c}\text { Doxycycline } \\
(8.0 \mathrm{mg} / \mathrm{l}) \\
\end{array}$ & $\begin{array}{c}\text { Amoxicillin } \\
(4.0 \mathrm{mgl}) \\
\end{array}$ \\
\hline \multirow{3}{*}{$\begin{array}{l}\text { El-Giza } \\
\text { DWTP }\end{array}$} & Raw Nile water & $1.9 \times 10^{7}$ & $\begin{array}{l}1.12 \times 10^{4} \\
(0.059 \%)\end{array}$ & $\begin{array}{c}6.2 \times 10^{3} \\
(0.033 \%)\end{array}$ & $\begin{array}{c}1.1 \times 10^{2} \\
(0.00058 \%)\end{array}$ & $\begin{array}{c}1.85 \times 10^{4} \\
(0.97 \%)\end{array}$ \\
\hline & $\begin{array}{c}\text { Treated Nile } \\
\text { water }\end{array}$ & $<1$ & $<1$ & $<1$ & $<1$ & $<1$ \\
\hline & Drinking water & $1.53 \times 10^{2}$ & $\begin{array}{c}81.0 \\
(52.94 \%) \\
\end{array}$ & $\begin{array}{c}63.0 \\
(41.18 \%) \\
\end{array}$ & $\begin{array}{c}10^{2} \\
(65.36 \%) \\
\end{array}$ & $\begin{array}{l}1.1 \times 10^{2} \\
(71.9 \%)\end{array}$ \\
\hline \multirow[t]{3}{*}{$\begin{array}{c}\text { El - Waraq } \\
\text { DWTP }\end{array}$} & Raw Nile water & $2.3 \times 10^{3}$ & $\begin{array}{c}9.0 \times 10^{2} \\
(39.13 \%) \\
\end{array}$ & $\begin{array}{c}10^{3} \\
(43.48 \%) \\
\end{array}$ & $\begin{array}{c}8.1 \times 10^{2} \\
(35.22 \%) \\
\end{array}$ & $\begin{array}{c}10^{2} \\
(4.35 \%) \\
\end{array}$ \\
\hline & $\begin{array}{c}\text { Treated Nile } \\
\text { water }\end{array}$ & $<1$ & $<1$ & $<1$ & $<1$ & $<1$ \\
\hline & Drinking water & $<1$ & $<1$ & $<1$ & $<1$ & $<1$ \\
\hline \multirow{3}{*}{$\begin{array}{c}\text { Gezeret El - } \\
\text { Dahab } \\
\text { DWTP }\end{array}$} & Raw Nile water & $2.1 \times 10^{2}$ & $\begin{array}{c}37.0 \\
(17.62 \%) \\
\end{array}$ & $\begin{array}{c}65.0 \\
(30.95 \%) \\
\end{array}$ & $\begin{array}{c}19.0 \\
(9.05 \%)\end{array}$ & $\begin{array}{c}30.0 \\
(14.29 \%) \\
\end{array}$ \\
\hline & $\begin{array}{c}\text { Treated Nile } \\
\text { water }\end{array}$ & $<1$ & $<1$ & $<1$ & $<1$ & $<1$ \\
\hline & Drinking water & $<1$ & $<1$ & $<1$ & $<1$ & $<1$ \\
\hline
\end{tabular}


amoxicillin resistant coliforms was $1.7 \%, 0.87$, $4.6 \%$ and $21.74 \%$ of total coliforms, respectively, in raw Nile water withdrawn from El-Giza DWTP. In Gezeret El-Dahab DWTP, the incidence of only gentamycin and amoxicillin resistant coliforms was observed with a percentage of $2.33 \%$ of total coliforms.

Fecal coliforms and fecal streptococci couldn't be recorded in any tested Nile water sample neither raw, treated nor tap water sample.

One sample of both raw and treated sewage withdrawn from Zenin WWTP was analyzed microbiologically to assess the prevalence of antibiotic resistant bacteria (Table 3). Counts and prevalence of all studied bacterial populations decreased by treatment of raw sewage. The total bacterial count decreased from $2.0 \times 10^{6}$ in raw sewage to $9.1 \times 10^{5} \mathrm{cfu} / \mathrm{ml}$ in treated sewage. Also, the prevalence of gentamycin, ciprofloxacin, doxycycline and amoxicillin resistant bacteria decreased from $19.5,15.0,40.5$ and $33.0 \%$ in raw sewage to 9.9 , $8.8,14.3$ and $16.5 \%$ in treated sewage, respectively. Completely disappearing of antibiotics resistant fecal coliforms and fecal streptococci was observed in treated sewage.

Only prevalence of total coliforms resistant to doxycycline and amoxicillin increased from 1.1 and $1.2 \%$ in raw sewage to 6.52 and $17.0 \%$, respectively in treated sample. Results in Table (3) indicate that, the counts and prevalence of fecal streptococci and their antibiotics resistant populations in raw sewage increased comparing with fecal coliforms and their antibiotics resistant counts.

\subsection{Antibiotic susceptibility test}

Raw Nile water and sewage samples were compared to each other to evaluate the prevalence of antibiotic resistant (AR) and multi antibiotic resistant (MAR) microorganisms (Table 4). The results in Table (4) could be summarized as the following:

3.2.1. The isolates from raw Nile water withdrawn from El-Giza DWTP were resistant to two antibiotics (52.4\%), three antibiotics (28.6\%) and four antibiotics (19.0\%). In the three classes, $\mathrm{G}^{-}$bacterial short rods were predominant at a ratio of $72.7,66.6$ and $75 \%$, respectively.

3.2.2. Raw Nile water sample from El-Waraq DWTP contained microbial cells resistant to two antibiotics $(80.0 \%)$ and three antibiotics (20.0\%). Gram-negative bacterial short rods represented 50.0 and $100.0 \%$ of the isolates

Table (3): Incidence of total bacteria, total coliforms, fecal coliforms, fecal streptococci and antibiotic resistant bacteria in raw and treated sewage from Zenin WWTP.

\begin{tabular}{|c|c|c|c|c|c|}
\hline \multirow[b]{2}{*}{ Water sample } & \multirow[b]{2}{*}{$\begin{array}{l}\text { Total count } \\
\text { (cfu/ml) }\end{array}$} & \multicolumn{4}{|c|}{ Microbial count resistant to } \\
\hline & & $\begin{array}{c}\text { Gentamycin } \\
(8.0 \mathrm{mg} / \mathrm{l})\end{array}$ & $\begin{array}{c}\text { Ciprofloxacin } \\
(2.0 \mathrm{mg} / \mathrm{l})\end{array}$ & $\begin{array}{c}\text { Doxycycline } \\
\text { (8.0 mg/l) }\end{array}$ & $\begin{array}{c}\text { Amoxicillin } \\
(4.0 \mathrm{mg} / \mathrm{l})\end{array}$ \\
\hline Raw sewage & $2.0 \times 10^{6}$ & $\begin{array}{l}3.9 \times 10^{5} \\
(19.5 \%)\end{array}$ & $\begin{array}{l}3.0 \times 10^{5} \\
(15.0 \%)\end{array}$ & $\begin{array}{l}8.1 \times 10^{5} \\
(40.5 \%)\end{array}$ & $\begin{array}{l}6.6 \times 10^{5} \\
(33.0 \%)\end{array}$ \\
\hline \multirow[t]{3}{*}{ Treated sewage } & $9.1 \times 10^{5}$ & $\begin{array}{l}9.0 \times 10^{4} \\
(9.9 \%)\end{array}$ & $\begin{array}{c}8.0 \times 10^{4} \\
(8.8 \%)\end{array}$ & $\begin{array}{l}1.3 \times 10^{5} \\
(14.3 \%)\end{array}$ & $\begin{array}{l}1.5 \times 10^{5} \\
(16.5 \%)\end{array}$ \\
\hline & & \multicolumn{4}{|c|}{ Total coliforms resistant to } \\
\hline & $\begin{array}{l}\text { Total coliforms } \\
(\mathrm{MPN} / \mathrm{mL})\end{array}$ & $\begin{array}{c}\text { Gentamycin } \\
(8.0 \mathrm{mg} / \mathrm{l})\end{array}$ & $\begin{array}{c}\text { Ciprofloxacin } \\
(2.0 \mathrm{mg} / \mathrm{l})\end{array}$ & $\begin{array}{c}\text { Doxycycline } \\
\text { (8.0 mg/l) }\end{array}$ & $\begin{array}{c}\text { Amoxicillin } \\
(4.0 \mathrm{mg} / \mathrm{l})\end{array}$ \\
\hline Raw sewage & $7.5 \times 10^{4}$ & $\begin{array}{l}4.0 \times 10^{2} \\
(0.53 \%)\end{array}$ & $\begin{array}{l}4.0 \times 10^{2} \\
(0.53 \%)\end{array}$ & $\begin{array}{c}8.0 \times 10^{2} \\
(1.1 \%)\end{array}$ & $\begin{array}{c}9.0 \times 10^{2} \\
(1.2 \%) \\
\end{array}$ \\
\hline \multirow[t]{3}{*}{ Treated sewage } & $2.3 \times 10^{2}$ & Nil & Nil & $\begin{array}{c}15.0 \\
(6.52 \%)\end{array}$ & $\begin{array}{c}39.0 \\
(17.0 \%)\end{array}$ \\
\hline & & \multicolumn{4}{|c|}{ Fecal coliforms resistant to } \\
\hline & $\begin{array}{l}\text { Fecal coliforms } \\
\text { (MPN/mL) }\end{array}$ & $\begin{array}{c}\text { Gentamycin } \\
(8.0 \mathrm{mg} / \mathrm{l})\end{array}$ & $\begin{array}{c}\text { Ciprofloxacin } \\
(2.0 \mathrm{mg} / \mathrm{l})\end{array}$ & $\begin{array}{c}\text { Doxycycline } \\
(8.0 \mathrm{mg} / \mathrm{l})\end{array}$ & $\begin{array}{l}\text { Amoxicillin } \\
(4.0 \mathrm{mg} / \mathrm{l})\end{array}$ \\
\hline Raw sewage & 80.0 & $\begin{array}{c}9.0 \\
(11.25 \%)\end{array}$ & $\begin{array}{c}4.0 \\
(5.0 \%)\end{array}$ & $\begin{array}{c}4.0 \\
(5.0 \%)\end{array}$ & $\begin{array}{c}4.0 \\
(5.0 \%)\end{array}$ \\
\hline \multirow[t]{3}{*}{ Treated sewage } & Nil & Nil & Nil & Nil & Nil \\
\hline & Fecal & \multicolumn{4}{|c|}{ Fecal streptococci resistant to } \\
\hline & $\begin{array}{l}\text { streptococci } \\
\text { (MPN/mL) }\end{array}$ & $\begin{array}{c}\text { Gentamycin } \\
(8.0 \mathrm{mg} / \mathrm{l})\end{array}$ & $\begin{array}{c}\text { Ciprofloxacin } \\
(2.0 \mathrm{mg} / \mathrm{l})\end{array}$ & $\begin{array}{c}\text { Doxycycline } \\
(8.0 \text { mg/l) }\end{array}$ & $\begin{array}{c}\text { Amoxicillin } \\
(4.0 \mathrm{mg} / \mathrm{l})\end{array}$ \\
\hline Raw sewage & 93.0 & $\begin{array}{c}75.0 \\
(80.6 \%)\end{array}$ & $\begin{array}{c}15.0 \\
(16.13 \%)\end{array}$ & $\begin{array}{c}43.0 \\
(46.2 \%)\end{array}$ & $\begin{array}{c}75.0 \\
(80.6 \%)\end{array}$ \\
\hline Treated sewage & Nil & Nil & Nil & Nil & Nil \\
\hline
\end{tabular}


Table (4): Incidence of antibiotic resistant (AR) and multi antibiotic resistant (MAR) microorganisms in raw Nile water and wastewater.

\begin{tabular}{|c|c|c|c|c|c|c|c|c|}
\hline \multirow[t]{2}{*}{ Isolation site } & \multirow{2}{*}{$\begin{array}{c}\text { Total } \\
\text { isolates }\end{array}$} & \multicolumn{7}{|c|}{ Number of isolates resistant to } \\
\hline & & $\begin{array}{c}1 \\
\text { antibiotic }\end{array}$ & $\begin{array}{c}2 \\
\text { antibiotics }\end{array}$ & $\begin{array}{c}3 \\
\text { antibiotics }\end{array}$ & $\begin{array}{c}4 \\
\text { antibiotics }\end{array}$ & $\begin{array}{c}5 \\
\text { antibiotics }\end{array}$ & $\begin{array}{c}6 \\
\text { antibiotics }\end{array}$ & $\begin{array}{c}7 \\
\text { antibiotics }\end{array}$ \\
\hline 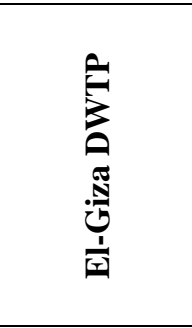 & 21 & 0.0 & $\begin{array}{c}11(52.4 \%) \\
\left(72.7 \% G^{-}\right. \\
\text {short rods } \\
18.2 \% G^{+} \\
\text {cocci } \\
9.1 \% G^{+} \\
\text {short rods }\end{array}$ & $\begin{array}{c}6(28.6 \%) \\
\\
66.6 \% G^{-} \\
\text {short rods } \\
16.7 \% G^{+} \\
\text {cocci } \\
16.7 \% \\
\text { yeast }\end{array}$ & $\begin{array}{c}4(19.0 \%) \\
75 \% G^{-} \\
\text {short rods } \\
25 \% \text { yeast }\end{array}$ & 0.0 & 0.0 & 0.0 \\
\hline 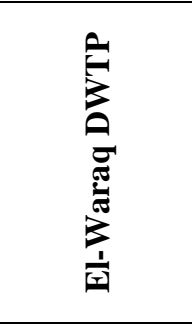 & 20 & 0.0 & $\begin{array}{c}16(80.0 \%) \\
50 \% \mathbf{G}^{-} \\
\text {short rods } \\
25 \% \mathbf{G}^{+} \\
\text {cocci } \\
25 \% \mathbf{G}^{+} \\
\text {short rods }\end{array}$ & $\begin{array}{c}4(20.0 \%) \\
100 \% G^{-} \\
\text {short rods }\end{array}$ & 0.0 & 0.0 & 0.0 & 0.0 \\
\hline 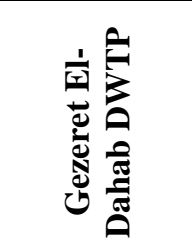 & 24 & 0.0 & $\begin{array}{c}4(16.7 \%) \\
100 \% G^{-} \\
\text {short } \\
\text { rods }\end{array}$ & $\begin{array}{c}4(16.7 \%) \\
100 \% G^{+} \\
\text {short rods }\end{array}$ & $\begin{array}{c}4(16.7 \%) \\
100 \% G^{-} \\
\text {short rods }\end{array}$ & 0.0 & $\begin{array}{c}4(16.7 \%) \\
100 \% G^{+} \\
\text {short rods }\end{array}$ & $\begin{array}{c}8(33.2 \%) \\
100 \% G^{-} \\
\text {short rods }\end{array}$ \\
\hline 影 & 25 & $\begin{array}{c}1(4.0 \%) \\
100 \% \\
G^{+} \text {cocci }\end{array}$ & $\begin{array}{l}6(24.0 \%) \\
83.3 \% G^{-} \\
\text {short rods } \\
16.7 \% G^{+} \\
\text {short rods }\end{array}$ & $\begin{array}{c}8(32.0 \%) \\
75 \% G^{-} \\
\text {short rods } \\
12.5 \% G^{+} \\
\text {short rods } \\
12.5 \% G^{+} \\
\text {cocci }\end{array}$ & $\begin{array}{c}8(32.0 \%) \\
100 \% G^{-} \\
\text {short rods }\end{array}$ & $\begin{array}{c}1(4.0 \%) \\
100 \% G^{-} \\
\text {short rods }\end{array}$ & 0.0 & $\begin{array}{c}1(4.0 \%) \\
100 \% G^{-} \\
\text {short rods }\end{array}$ \\
\hline
\end{tabular}

resistant to two and three antibiotics, correspondingly.

3.2.3. From raw Nile water samples, the sample withdrawn from Gezeret El-Dahab was prevalent with diverse antibiotic resistant bacteria. The microbial population resistant to $2,3,4$ or 6 antibiotics represented $16.7 \%$ for each group. The isolates resistant to seven antibiotics represented $33.2 \%$. Gram-negative short rods were predominant in the microbial community resistant to 2, 4 or 7 antibiotics. Conversely, all isolates resistant to 3 or 6 antibiotics were Grampositive rods.

3.2.4. In raw sewage, the microbial isolates were resistant to $1,2,3,4,5$ and 7 antibiotics with a percentage of 4.0, 24.0, 32.0, 32.0, 4.0 and 4.0\%, respectively. The Gram-negative short rods were predominant in all microbial groups, except that resistant to one antibiotic.
Also, it was observed that, all isolates from all water samples were resistant to ampicillin (10 $\mu \mathrm{g})$. The majority of isolates of raw Nile water from El-Giza DWTP and raw sewage were resistant to amoxicillin $(25 \mu \mathrm{g})$ with a ratio of 66.7 and $68.0 \%$, respectively.

\section{DISCUSSION}

The antibiotics are one of the most important pharmaceuticals used for human and veterinary therapy. According to the chemical structure, the antibiotics are classified into eight groups; betalactams, aminoglycosides, quinolones, tetracyclines, sulfonamides, macrolides, carbapenems and cephalosporins. The antibiotics have essential applications to improve human and animal health through prevention and treatment of infectious diseases caused by pathogenic bacteria. Also, the antibiotics are 
applied to promote animal growth as they could be used as fodder additives at low concentrations and as coccidiostats in the poultry industry to retard the growth and reproduction of coccidian parasites (Bouki et al., 2013). The intense and ultimate use of antibiotics stimulates the pervasion and development of the antibiotic resistant bacteria (ARB). The incidence of antibiotic resistant bacteria is insistent public health problem worldwide as they could be easily transmitted to humans through ingestion of contaminated food, drinking contaminated water and contact with infected humans or animals (Chang et al., 2015).

The aquatic ecosystems are considered as a reservoir for $\mathrm{ARB}$ and antibiotic resistance genes (ARGs) (Xi et al., 2009 and Zhang et al., 2009).

The present study focused on assessing the incidence of ARB in different types of water in Egypt especially raw and treated Nile water. It is obviously that, the drinking water treatments in all DWTPs were effective microbiologically as the total bacterial community and antibiotics resistant bacteria were completely removed from treated Nile water and tap water samples. Only, in El-Giza DWTP the bacterial populations reappeared in tap water with low values comparing with raw Nile water. The counts of bacterial population, gentamycin, ciprofloxacin, doxycycline and amoxicillin resistant bacteria in tap water represented $0.0008,0.72,1.02,90.9$ and $0.6 \%$ of the counts in raw Nile water. The complete removal of bacteria and ARB from treated Nile water and tap water from El-Waraq and Gezeret El-Dahab DWTPs could be interpreted by the strong bactericidal effect of the disinfection process in this DWTPs. The regrowth of bacteria in tap water from El-Giza DWTP may be attributed to weak bactericidal effect of the disinfection process which permits the reactivation of bacteria in the drinking water distribution system. Several studies reported the presence of ARB in drinking water systems (Armstrong et al., 1982; Schwartz et al., 2003; Pavlov et al., 2004; Xi et al., 2009 and Zhang et al., 2009). The absence of fecal coliforms and fecal streptococci in raw Nile water indicated that, there is no leakage of domestic wastewater into the Nile stream in the geographic area near the selected drinking water treatment plants.

The antibiotics are released into WWTPs from different sources comprised domestic source, clinical source from the hospitals and industrial source from mainly the pharmaceuticals factories (Nagulapally et al., 2009).

Waste water treatment is a process applied to reduce all contaminants, including bacteria and toxic chemicals, to the acceptable levels. By this process, the waste water is converted to safe effluent to be discarded into the environment. Usually, the waste water treatment includes three stages called primary, secondary, and tertiary treatment. In primary treatment, the sewage is placed in a basin to separate heavy solids in the bottom. Secondary treatment is applied biologically and chemically to remove the most of organic matter. In tertiary treatment, some additional processes are used to remove components, which are not removed by the secondary treatment.

Generally, there are two concepts to discuss the effect of wastewater treatment on the prevalence of ARB in wastewater. Some studies reported that the conditions in wastewater treatment plants (WWTPs) are convenient to improve the reproduction of ARB and transferring resistance genes to non-resistant bacteria. Conversely, other studies stated that the wastewater treatments remove the ARB efficiently from sewage (Guardabassi et al., 2002; Huang et al., 2012; Bouki et al., 2013; Xu et al., 2015; Sharma et al., 2016 and Li et al., 2017).

In our investigation, it was observed that the counts of total bacteria, gentamycin, ciprofloxacin, doxycycline and amoxicillin resistant bacteria decreased in treated wastewater with a reduction percentage of 54.5, 76.9, 73.3, 84.0 and $77.3 \%$, respectively. Also, it was noticed that, the counts of total coliforms, doxycycline and amoxicillin resistant coliforms decreased at a reduction ration of 99.7, 98.125 and $95.7 \%$, respectively, in treated waste water. Additionally, the gentamycin and ciprofloxacin resistant bacteria disappeared totally in treated waste water. These results support the fact of removing or decreasing the counts of ARB by WWTPs. It is important to recognize that, although the count of ARB could be reduced in the effluent of WWTP at a ratio reaching up to $98.125 \%$ but this effluent still has amounts of ARB which could be transferred to subsequent environments, posing a potential threat to their safety and public health. These ARB could be characterized by higher resistance to antibiotics due to the transfer of genes between bacteria present in the wastewater (Reinthaler et al., 2003; Börjesson et al., 2009; Yuan et al., 2014 
and Osińska et al., 2017). Comprehensive disappearance of fecal coliforms, fecal streptococci and corresponding ARB might be attributed to their low density in the wastewater which facilitate their removing by treatment process.

Robert and Steven (2012) stated that E. coli isolate is characterized as antibiotic resistant (AR) if it was resistant to one from five tested antibiotics, and multiple antibiotic resistant (MAR) if it was resistant to at least two tested antibiotics. Accordingly, it could be concluded that, the most bacterial isolates from raw Nile water and sewage were MAR as they were resistant to $2,3,4,5,6$ or 7 antibiotics from tested seven antibiotics. The predominance of Gram-negative bacteria in the microbial population resistant to the tested antibiotics is expected because they have the unique outer membrane which determines the permeability and sensitivity of the cells to the antimicrobial agents as explained by Yokota and Fujii (2007). In the current study, most ARB were resistant to ampicillin and amoxicillin. These antibiotics are aminopenicillins with the chemical structure of beta-lactam ring and a side chain. The betalactam ring is responsible for antimicrobial activity, and the side chain determines the antibacterial spectrum and pharmacologic properties. The antibacterial activity of these antibiotics is represented by inhibition of the bacterial cell wall synthesis through prevention of the transpeptidation reaction.

Finally, it could be concluded that, the bacterial isolates obtained from raw Nile water and sewage exhibited multi-resistance to numerous antibiotics from different classes. These bacteria may have the ability to cause severe diseases in human. Therefore, the sewage should be treated and disinfected effectively before its disposal in the environmental water to prevent the prevalence of antibiotic resistant bacteria.

\section{REFERENCES}

Abdo M. H. (2005). Physico-chemical characteristics of Abu Za'baal ponds, Egypt. Egypt J. of Aquatic Res., 31(2): 115.

Armstrong J., Calomiris J. and Seidler R. (1982). Selection of antibiotic-resistant standard plate count bacteria during water treatment. Appl. Envi. Micro., 44:308-316.

Bauer A., Kirby, W., Sherris J. and Turck, M. (1966). Antibiotic susceptibility testing by a standardized single disk method. Am. J. Clin. Pathol., 45(4):493-496.

Berry D., Xi C. and Raskin L. (2006). Microbial ecology of drinking water distribution systems. Curr. Opin. Biotch. 17:297-302.

Börjesson S., Melin S., Matussek A. and Lindgren P. (2009). A seasonal study of the mecA gene and Staphylococcus aureus including methicillin-resistant $\mathrm{S}$. aureus in a municipal wastewater treatment plant. Water Res.43(4):925932.

Bouki C., Venieri D. and Diamadopoulos E. (2013). Detection and fate of antibiotic resistant bacteria in wastewater treatment plants: A review. Ecotox. and Enviro. Safety, 91:1-9.

Chang Q., Wang W., Regev-Yochay G., Lipsitch $M$ and Hanage W. (2015). Antibiotics in agriculture and the risk to human health: how worried should we be? Evol. Appl. 8(3): 240-247.

Cytryn E. (2013). The soil resistome: The anthropogenic, the native, and the unknown. Soil Bio. Biochem., 63:18-23.

Davies J. (2006). Are antibiotics naturally antibiotics? J. Ind. Micro. Biotec., 33 (7): 496-499.

Devarajan N., Lafffite A. Mulaji C., Otamonga J., Mpiana P., Mubedi J., Prabakar K., Ibelings B. and Poté J. (2016). Occurrence of antibiotic resistance genes and bacterial markers in a tropical river receiving hospital and urban wastewaters. PLoS One., 11(2): e0149211,

Guardabassi L., Wong D. and Dalsgaard A. (2002). The effects of tertiary wastewater treatment on the prevalence of antimicrobial resistant bacteria. Water Res., 36:1955-1964.

Harrigan W. (1998). Detection and enumeration of indicator and index organisms. In: "Laboratory methods in food microbiology" $3^{\text {rd }}$ ed., Academic Press, California, USA, p. 164-174.

Huang J., Hu H., Lu S., Li Y., Tang F., Lu, Y. and Wei B. (2012). Monitoring and evaluation of antibiotic-resistant bacteria at a municipal wastewater treatment plant in China. Environ. Int'1., 42: 31-36.

Leonard A., Zhang L., Balfour A., Garside R. and Gaze W. (2015). Human recreational exposure to antibiotic resistant bacteria in coastal bathing waters. Environ. Int'l., 82: 92- 100 . 
Li N., Sheng G., Lu, Y., Zeng, R. and Yu H. (2017). Removal of antibiotic resistance genes from wastewater treatment plant effluent by coagulation. Water Res. 111: 204-212.

Ma L., Li B and Zhang T. (2014). Abundant rifampin resistance genes and significant correlations of antibiotic resistance genes and plasmids in various environments revealed by metagenomic analysis. Appl. Micr. and Biotech., 98: 5195-5204.

Marti E., Huerta B., Rodríguez-Mozaz S., Barceló D., Jofre J and Balcázar J. (2014). Characterization of ciprofloxacin-resistant isolates from a wastewater treatment plant and its receiving river. Water Res.,15 (61):67-76.

Martinez J. (2008). Antibiotics and antibiotic resistance genes. Natural Environ. Scie. 18:321(5887):365-367

Michael I., Rizzo L., McArdell C., Manaia C., Merlin C., Schwartz T., Dagot $\mathrm{C}$ and Fatta-Kassinos D. (2013). Urban waste water treatment plants as hotspots for the release of antibiotics in the environment: a review. Water Res. 47 (3): 957-995.

Nagulapally S., Ahmad A., Henry A., Marchin G., Zurek L and Bhandari A. (2009). Occurrence of ciprofloxacin-, trimethoprimesulfamethoxazole-, and vancomycin-resistant bacteria in a municipal wastewater treatment plant. Water Environ. Res., 81:82-90.

Osinska A., korzeniewska E., Harnisz M. and Niestepskski S. (2017). Impact of type of waste water treatment process on the antibiotic resistance of bacterial populations. E3S Web of Conferences 17, 00070.

Pathak S. and Gopal. K. (2008). Prevalence of bacterial contamination with antibioticresistant and enterotoxigenic fecal coliforms in treated drinking water. J. Toxicol. Environ. Health., 71:427-433.

Pavlov D., de Wet C., Grabow W. and Ehlers M. (2004). Potentially pathogenic features of heterotrophic plate count bacteria isolated from treated and untreated drinking water. Int'l J. Food Micro., 92:275-287.

Pochon J. and Tardieux P. (1962). Techniqued, Analyseen microbiology du sol. Editions de la tourlle, St. mande. France.

Pruden A., Arabi M. and Storteboom H. (2012). Correlation between upstream human activities and riverine antibiotic resistance genes. Environ. Sci. and Techn., 46:11541-11549.

Ramteke P., Gaur A., Pathak S. and Bhattacharjee J. (1990). Antibiotic resistance of coliforms in drinking water in rural areas. Indian J. Med. Res., 91: 185-188.

Reinthaler F., Posch J., Feierl G., Wüst G., Haas D., Ruckenbauer G., Mascher F. and Marth E. (2003). Antibiotic resistance of Escherichia coli in sewage and sludge. Water Res., 37(8):1685-1690.

Robert E. and Steven E. (2012). Antibiotic resistance of Escherichia coli isolated from a stream near two wastewater treatment facilities in Edmond, Oklahoma. Proc. Okla. Acad. Sci. 92: 59-64.

Schwartz T., Kohnen W., Jansen B. and Obst U. (2003). Detection of antibiotic-resistant bacteria and their resistance genes in waste-water, surface water, and drinking water biofilms. FEMS Micro. Ecol.,43: 325-335.

Sharma V., Johnson N., Cizmas L., McDonald T. and Kim H. (2016). A review of the influence of treatment strategies on antibiotic resistant bacteria and antibiotic resistance genes. Chemosphere. 150: 702714.

Shrivastava R. Upreti R., Jain S., Prasad K., Seth P. and Chaturvedi U. (2004). Suboptimal chlorine treatment of drinking water leads to selection of multidrug resistant Pseudomonas aeruginosa. Ecoto,xicol. Environ. Saf. 58: 277-283.

Vozmaya N. F. (1983). Chemistry of water \& microbiology: Mir Publishers, 2 pervyrizhskyperevlok, I-110 GSP, Moscow, 19820 USSR.

Walia S., Kaiser A., Parkash M. and Chaudhry G. (2004). Self-transmissible antibiotic resistance to ampicillin, streptomycin and tetracyclin found in Escherichia coli isolated from contaminated drinking water. J. Enviro. Sci. and Health. 39: 65162.

Xi C., Zhang Y., Marrs C., Ye W., Simon C., Foxman B. and Nriagu J. (2009). Prevalence of antibiotic resistance in drinking water treatment and distribution systems. Appl. and Environ. Microbial., 75 (17): 5714 -5718.

Xu J., Xu Y., Wang H., Guo C., Qiu H., He Y and Zhang $Y$ (2015). Occurrence of 
antibiotics and antibiotic resistance genes in a sewage treatment plant and its effluent-receiving river. Chemosphere., 119: 1379-1385.

Yokota S. and Fujii, N. (2007). Contributions of the lipopolysaccharide outer core oligosaccharide region on the cell surface properties of Pseudomonas aeruginosa. Comp. Immunol. Microb. Infect. Dis., 30: 97-109.

Yuan Q., Guo M. and Yang J. (2014). Monitoring and assessing the impact of wastewater treatment on release of both antibiotic-resistant bacteria and their typical genes in a Chinese municipal wastewater treatment plant. Environ. Sci. Process. Impacts.,16(8):1930-1937.

Zhang X., Zhang T. and Fang. H. (2009). Antibiotic resistance genes in water enviro. Appl. Microb. Biotech., 82:397414.

Zhang Y., Marrs C., Simon C. and Xi C. (2009). Waste water treatment contributes to selective increase of antibiotic resistance among Acinetobacter spp. Sci. Total Environ., 407:3702-3706.

$$
\begin{aligned}
& \text { مدى انتثار البكتيريا المقاومة للمضادات الحيوية في مياه النيل ومحطات معالجة مياه الصرف الصحي } \\
& \text { دينا علي أحمد ـ حنان عبداللطيف جودة - رفاعي إبراهيم رفاعي } \\
& \text { قسم الميكروبيولوجي ـ كلية الزر اعة ـ جامعة القاهرة - جيزة - القاهرة }
\end{aligned}
$$

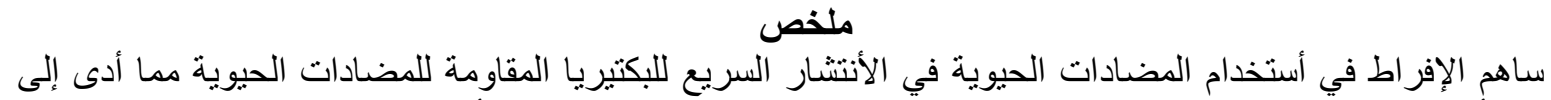

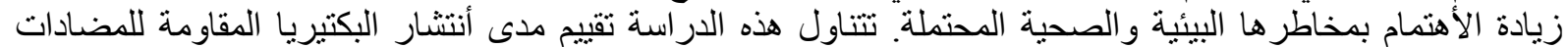

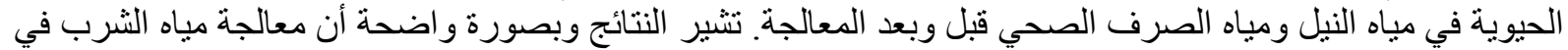

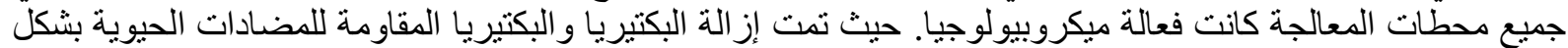
كامل من مياه النيل المعالجة وكذلك عينات مياه الصنبور. لوحظ فقط في محطة الجيزة لمعالجة مياه الثرب فئ ظهور التجمعات البكتيرية مرة أخرى في مياه الصنبور مع أنخفاض أعدادها مقارنة بمياه النيل غير المعالجة. تمثل أعداد أعداد البكتيريا

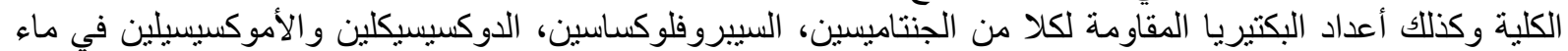

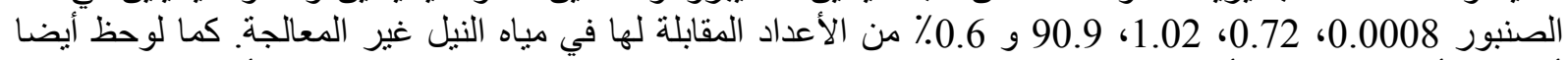

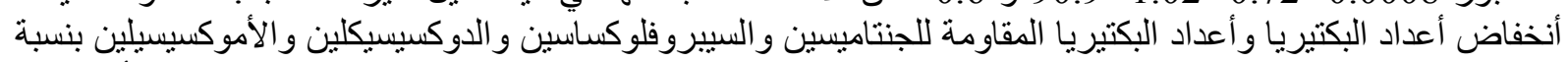

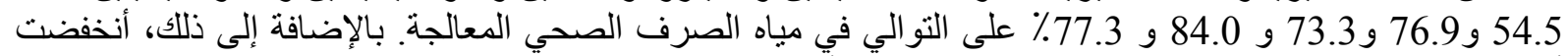

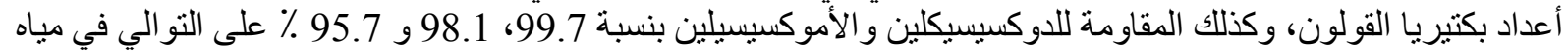

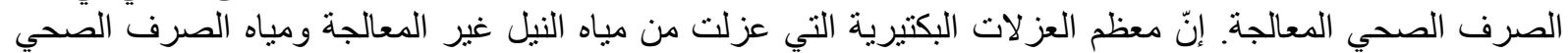

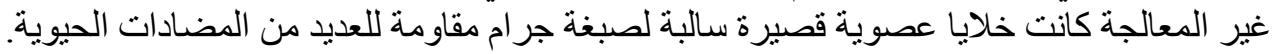
المجلة العلمية ـ كلية الزراعة - جامعة القاهرة ـ المجلا (69) العدد الرابع (أكتوبر الجئ 2018): 427-435. 